\title{
Influence of Airflow on Laboratory Storage of High Moisture Corn Stover
}

\author{
Lynn M. Wendt • Ian J. Bonner • Amber N. Hoover • \\ Rachel M. Emerson • William A. Smith
}

Published online: 17 April 2014

(C) The Author(s) 2014. This article is published with open access at Springerlink.com

\begin{abstract}
Storing high moisture biomass for bioenergy use is a reality in many areas of the country where wet harvest conditions and environmental factors prevent dry storage from being feasible. Aerobic storage of high moisture biomass leads to microbial degradation and self-heating, but oxygen limitation can aid in material preservation. To understand the influence of oxygen presence on high moisture biomass (50\%, wet basis), three airflow rates were tested on corn stover stored in laboratory reactors. Temperature, carbon dioxide production, dry matter loss, chemical composition, fungal abundance, $\mathrm{pH}$, and organic acids were used to monitor the effects of airflow on storage conditions. The results of this work indicate that oxygen availability impacts both the duration of self-heating and the severity of dry matter loss. High airflow systems experienced the greatest initial rates of loss but a shortened microbially active period that limited total dry matter loss (19\%). Intermediate airflow had improved preservation in short-term storage compared to high airflow systems but accumulated the greatest dry matter loss over time (up to $27 \%$ ) as a result of an extended microbially active period. Low airflow systems displayed the best performance with the lowest rates of loss and total loss (10\%) in storage at 50 days. Total structural sugar levels of the stored material were preserved, although glucan enrichment and xylan loss were documented in the high and intermediate flow conditions. By understanding the role of oxygen availability on biomass storage performance, the requirements for high moisture storage solutions may begin to be experimentally defined.
\end{abstract}

L. M. Wendt $(\bowtie) \cdot$ W. A. Smith

Biological and Chemical Processing Department, Idaho National Laboratory, P.O. Box 1625, Idaho Falls 83415, USA

e-mail: lynn.wendt@inl.gov

I. J. Bonner · A. N. Hoover • R. M. Emerson

Biofuels and Renewable Energy Technologies Department, Idaho

National Laboratory, P.O. Box 1625, Idaho Falls 83415, USA
Keywords Biomass $\cdot$ Corn stover $\cdot$ Aerobic storage $\cdot$ Aeration rate $\cdot$ Dry matter loss $\cdot$ Composition

\section{Introduction}

Large quantities of biomass are necessary to supply emerging bioenergy conversion facilities, on the scale of 2,100 tons per day for a 61-million gal per year biorefinery [1]; however, the challenge is to provide a consistent supply of biomass throughout the year since most agricultural residues are seasonally harvested and will require extended on-farm storage. Corn stover is one such residue that has gained considerable attention as a bioenergy feedstock due to its current availability and collection infrastructure, and it is estimated that up to 256 million tons per year could be sustainably harvested [2]. Moisture levels of less than $20 \%$ wet basis (wb; the mass of water relative to the combined masses of water and dry matter) are recommended to prevent microbial growth and biomass degradation in aerobic storage of corn stover [3], yet higher moisture contents are inevitable in many areas of the country due to grain harvest conditions, residue collection methods that prevent or reduce in-field drying (i.e., single-pass harvesting), or wetting of the material while in storage [4]. The uncertainties of managing these high moisture labile materials must be addressed if robust storage management solutions are to be implemented into the feedstock supply chain.

Degradation of biomass occurs as a result of microorganisms growing in the presence of ample moisture, oxygen, and substrate, resulting in the production of carbon dioxide and heat. The self-heating of high moisture biomass due to respiration causes temperatures to reach $65^{\circ} \mathrm{C}$ or higher within days of storage, and temperatures can remain elevated for weeks to months $[5,6]$. Dry matter losses of up to $40 \%$ have been documented in aerobically stored piles of high moisture corn stover (wetted to over $70 \%$ wb by precipitation) after 8 months in storage [7]. Even 
near the target threshold of $20 \%{ }_{\mathrm{wb}}$ moisture, baled corn stover at $22 \% \%_{\text {wb }}$ moisture has been shown to lose $14 \%$ dry matter after only 3 months in storage [8]. The stability of stored materials must be improved if biomass is to retain its value to the producer and conversion facility for up to 12 months.

While moisture loss is difficult to predict and substrate availability is largely fixed in field scenarios, oxygen exclusion in storage has proven to be beneficial to dry matter preservation. Oxygen availability in stored biomass is dependent on the storage method (piles or bales, stack size and orientation, physical barriers) and biomass properties (particle size, moisture content, and packing density) [9, 10]. Stacks of bales are the preferred biomass storage format for emergent biorefineries [11], but they do not naturally exclude oxygen. Free airspace in high moisture corn stover bales can range from 53 to $69 \%$, as calculated using average bale densities of 130-200 kg dry matter (DM) $/ \mathrm{m}^{3}$ and average particle densities of $740 \mathrm{~kg} \mathrm{DM} / \mathrm{m}^{3}[12,13]$. Decomposition of aerobically stored organic matter is reported to be negatively impacted at free airspaces of less than $30 \%$ and optimized at $85 \%[9,14]$; therefore, the amount of free airspace in high moisture bales makes them especially susceptible to aerobic degradation. In contrast, corn silage stored in silos and bunkers is reported to have an average packing density of $235 \mathrm{~kg} \mathrm{DM} / \mathrm{m}^{3}[15,16]$, which equates to $25-45 \%$ estimated free airspace and is much closer to the recommended degradation-limiting range. Dry matter losses are often considered to be negligible in silage because anaerobic conditions reduce the possibility of deleterious microbial growth. However, because the packing density of baled biomass is limited by mechanical capabilities, oxygen availability must be manipulated by alternative options. The practice of bale wrapping greatly reduces oxygen availability in low density biomass and has been demonstrated to result in dry matter losses of less than $5 \%$ in high moisture corn stover bales [3]. While such evidence supports management of oxygen in biomass storage, not enough information exists on how varied degrees of oxygen limitation impact storage behavior and how this relationship can be used to improve storage practices.

Although oxygen limitation is clearly beneficial in principle, the measurement of oxygen availability in large, open systems is challenging. Laboratory-scale storage experiments provide a controlled environment to focus on the effect of a single variable while also presenting the advantages of lower cost and material requirements compared to field studies. Airflow is one variable easily controlled in laboratory reactors to alter oxygen availability. Multiple studies on degradation of organic matter have shown that aeration rate significantly affects self-heating profiles and rates of degradation, with low airflows reducing total organic matter decomposition by up to $20 \%$ compared to respective high flow tests [17-20].

Stable biomass storage is currently defined as either dry aerobic storage (less than $20 \%$ wb moisture) or anaerobic wet storage (greater than $50 \%$ wb moisture), with few recommendations for the dry matter preservation of $20-50 \% \%_{\text {wb }}$ moisture biomass. Moisture-tolerant aerobic storage systems have not been well characterized but would provide flexibility to the biomass supply chain, especially considering year-to-year variations in feedstock moisture content where dry storage cannot be achieved [21]. The objective of this research is to determine if changes in oxygen availability, as opposed to drying materials prior to storage or completely limiting oxygen in anaerobic wet storage, can be used to reduce the microbial degradation rate of high moisture corn stover in storage and, therefore, extend the storage period of inherently unstable materials. Limited studies on aeration tactics to preserve dry matter have been investigated in the field and range from high aeration with the intent to remove moisture (i.e., aerated silo tubes) to oxygen limitation techniques to encourage ensiling (i.e., bale wraps) [7, 22]. This paper describes the effect of three aeration rates during corn stover storage on the rate of material loss, the total dry matter loss, and resultant composition changes after storage in laboratory reactors, and it is the first study to focus on the levels of aeration that could reduce real-time dry matter loss rates.

\section{Methods}

\section{Reactor Design and Operation}

Six laboratory-scale reactors were used to simulate aerobic storage of corn stover (Fig. 1). The insulated 100-L reactors used a temperature-controlled water jacket to allow the biomass temperature to be driven by microbial heat generation and minimize heat loss. The mean temperature of the biomass was monitored by two PT-100 RTDs placed in the center of the material column at one third and two thirds of the height. A LabView computer interface (Version 11.0.1, National Instruments, Austin, TX) recorded biomass temperature data and controlled the circulating water jacket to $0.5{ }^{\circ} \mathrm{C}$ below the mean temperature of the biomass, with the purpose of minimizing conductive heat loss, thus simulating the thermal gradient and self-insulating properties of a pile or stack of baled self-heating biomass.

Instrument air regulated by mass flow controllers was supplied in a constant upward flow through the biomass column at $0.25,1.0$, and $2.5 \mathrm{~L} / \mathrm{min}( \pm 0.05)$ to the reactors in duplicate pairs (referred to as low, intermediate, and high flow, respectively). Airflow rates were chosen based on preliminary trials using pine chips and corn stover that showed typical selfheating behavior without excessive convective cooling of the sample mass in the airflow range tested here (data not shown). The airstream was heated and humidified by infusing inlet air through a porous frit submerged in 5 to $7.5 \mathrm{~cm}$ of deionized water below the packed biomass. Off-gas exhausted through 
Fig. 1 Operational illustration of the laboratory reactor system. a LabView control interface and data logging, $\mathbf{b}$ gas chromatograph, $\mathbf{c}$ heated water circulator, $\mathbf{d}$ vapor condenser, e reactor loaded with biomass in operation, $\mathbf{f}$ mass flow controlled gas supply

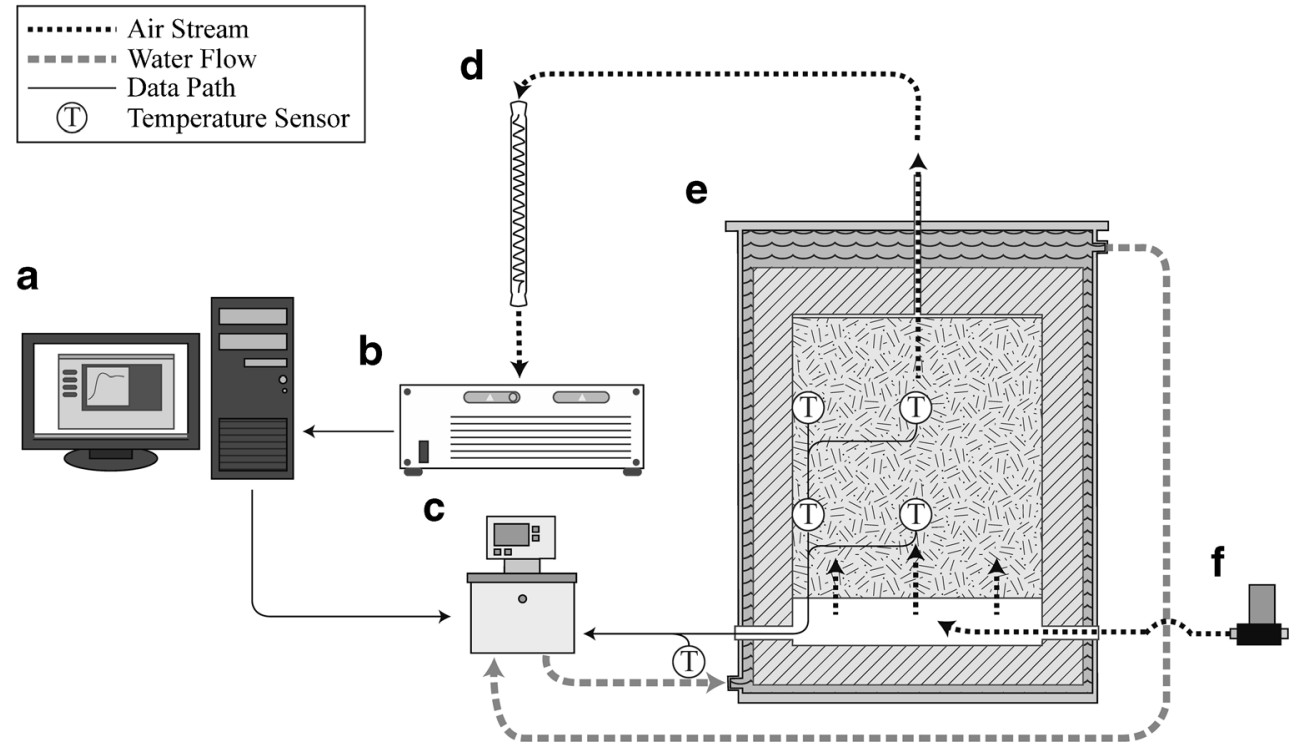

mass-based approach, both $\mathrm{DM}_{\mathrm{I}}$ and $\mathrm{DM}_{\mathrm{F}}$ were calculated by correcting the wet mass measured at loading and unloading for moisture content. A second approach was used to measure dry matter loss throughout the storage duration in addition to total dry matter loss by the use of respirometry. The mass of $\mathrm{CO}_{2}$ exiting the reactors was related to a consumption of carbohydrate $\left(\mathrm{CH}_{2} \mathrm{O}\right)_{n}$ using a molar ratio of 1:1 [24]. The cumulative mass of $\left(\mathrm{CH}_{2} \mathrm{O}\right)_{n}$ lost over time then replaced the numerator of Eq. 1, yielding Eq. 2:

$\% \mathrm{DML}=\Sigma\left(\mathrm{CH}_{2} \mathrm{O}\right)_{n} / \mathrm{DM}_{\mathrm{I}} \cdot 100$

grain harvest in Stevens County, KS by a single-pass baling operation (AGCO Challenger 680B combine and LB34B baler). One freshly harvested large rectangular bale was deconstructed without subsequent size reduction and packed into drums immediately, transported by vehicle to Idaho, and stored at $-20{ }^{\circ} \mathrm{C}$ until use in this experiment. The combination of sealed drums and frozen storage limited both moisture and dry matter loss. The corn stover packed in the reactors had an initial mean moisture content of $51.9 \pm 2.0 \%_{\mathrm{wb}}(n=6)$. The reactors were loaded with a mean of $8.2 \pm 0.4 \mathrm{~kg} \mathrm{DM}$, resulting in a mean packing density of $96.7 \pm 4.9 \mathrm{~kg} \mathrm{DM} / \mathrm{m}^{3}(n=6)$. All reactors were operated for 50 days. At the time of deconstruction, the biomass from each reactor was homogenized by hand and spread in a thin layer from which nine random samples were collected and composited for representative analyses. Moisture content was determined by drying a composite sample at $105^{\circ} \mathrm{C}$ for $24 \mathrm{~h} \mathrm{[23].}$

Dry matter loss was calculated using Eq. 1:

$\%$ Dry Matter Loss $(\mathrm{DML})=\left(\mathrm{DM}_{\mathrm{I}}-\mathrm{DM}_{\mathrm{F}}\right) / \mathrm{DM}_{\mathrm{I}} \cdot 100(1)$

where $\mathrm{DM}_{\mathrm{I}}$ is the dry matter mass entering the reactor and $\mathrm{DM}_{\mathrm{F}}$ is the dry matter mass exiting the reactor. In a simple where $\Sigma\left(\mathrm{CH}_{2} \mathrm{O}\right)_{n}$ is the mass of carbohydrate lost at any point in time. By using this $\mathrm{CO}_{2}$-based method, dry matter loss values are dependent only on the moisture measurements that determine the initial dry mass of the stover. Heating degree days (HDD) were determined by calculating the degrees magnitude that the temperature at the center of each reactor was above $30{ }^{\circ} \mathrm{C}$ and then summing the values over the total storage time.

\section{Microbial Analysis}

To estimate fungal abundance, most probable number (MPN) analysis was performed on the unstored and stored corn stover composite samples. Water extracts were prepared by creating a 1:10 ratio of wet biomass $(50 \mathrm{~g})$ to $\mathrm{BupH}$ phosphate buffered saline (Thermo Scientific, Rockford, IL) and shaking at $200 \mathrm{rpm}$ for $3 \mathrm{~h}$ at room temperature. Fungal plate MPNs were performed based on the method by Watanabe et al. [25] using potato dextrose agar with $100 \mathrm{mg} / \mathrm{L}$ chloramphenicol and were incubated at room temperature for 10 days. All MPNs were performed with dilutions from $10^{-2}$ to $10^{-7}$ in 
triplicate. A final MPN estimation was calculated in MS Excel as described by Briones and Reichardt [26] for each reactor. The results for each airflow condition were averaged for the duplicate reactors with the exception of the unstored material, where a duplicate sample was not taken. Results are reported as colony-forming units per gram dry matter [CFU/g DM].

\section{Chemical Analysis}

Organic acids were extracted from the unstored and stored corn stover composite samples in duplicate using a 1:10 ratio of wet biomass $(50 \mathrm{~g})$ to $18 \mathrm{M} \Omega \mathrm{cm}$ nanopure water. Samples were allowed to equilibrate at $4{ }^{\circ} \mathrm{C}$ for $72 \mathrm{~h}$. An aliquot was filtered to $0.2 \mu \mathrm{m}$ and acidified to a $\mathrm{pH}$ of 4 with sulfuric acid. Organic acids were analyzed using high-performance liquid chromatography (HPLC) with a refractive index (RI) detector (Waters, Milford, MA).

Chemical compositional analysis on unstored and stored corn stover composite samples was measured in duplicate according to standard biomass procedures developed by the National Renewable Energy Laboratory (NREL) [27]. Extractives from ethanol and water were determined using an ASE 350 (Dionex, Sunnyvale, CA) [28]. The extracted biomass was subjected to a two-stage acid hydrolysis [29]. The liquor from the acid hydrolysis was analyzed using HPLC with a RI detector for monomeric sugars and sugar degradation products (Agilent, Santa Clara, CA) [29]. Acid-soluble lignin fractions were analyzed using a Varian Cary 50 ultraviolet-visible spectrometer (Agilent, Santa Clara, CA) [29]. NREL's theoretical yield calculator was used to predict theoretical ethanol yields (TEY) [30].

\section{Statistical Analysis}

Averages and one standard deviation are presented with $n=2$ unless otherwise noted. Statistical analyses were performed in the open-source language R (version 2.14.0) [31]. One-way analysis of variance (ANOVA) was performed to identify significant differences, and Tukey's honest significant difference (HSD) test was performed for multiple level comparison of statistical equivalency.

\section{Results and Discussion}

\section{Storage Performance}

The self-heating and $\mathrm{CO}_{2}$ generation profiles of the three airflows were measured throughout the 50-day storage period (Fig. 2). Table 1 contains additional reactor details including moisture content, packing density, and dry matter loss.

The three-stage temperature profile associated with aerobic storage of organic matter was observed and used as a means to compare reactor performance. Briefly, this profile consists of a rapid increase in temperature to $65-70{ }^{\circ} \mathrm{C}$, followed by a prolonged high temperature plateau at $55-60{ }^{\circ} \mathrm{C}$, and finally rapid cooling to near ambient temperatures (which will be referred to as below $30{ }^{\circ} \mathrm{C}$ in this study for simplicity) [32]. The self-heating profiles were similar between all of the duplicate reactors, with the exception of the cooling exhibited by one intermediate flow reactor. The duplicate intermediate flow reactors had near-identical temperature and $\mathrm{CO}_{2}$ profiles for the majority of the storage duration and, therefore, are considered to have the same overall performance with exceptions noted.

Self-heating began rapidly in all treatments upon system startup, as depicted in Fig. 2. In the high and intermediate flow reactors, the biomass temperature reached a maximum of 65 and $67{ }^{\circ} \mathrm{C}$ in 2 days, respectively. Stover in the low flow reactors exhibited a slower temperature rise over 5 days and reached a maximum temperature of $68{ }^{\circ} \mathrm{C}$; this is consistent with the decreased rates of initial self-heating and slightly higher maximum temperatures observed in composting reactors with low flow rates $[17,18]$. The maximum amount of $\mathrm{CO}_{2}$ generated occurred during the initial heating phase by the second day of storage and ranged from $8.2 \pm 0.6 \mathrm{~L} \mathrm{CO}_{2} / \mathrm{h}$ for the high flow, $9.4 \pm 1.6 \mathrm{~L} \mathrm{CO}_{2} / \mathrm{h}$ for the intermediate flow, and $3.6 \pm 0.2 \mathrm{~L} \mathrm{CO}_{2} / \mathrm{h}$ for the low flow reactors. When mole percent of $\mathrm{CO}_{2}$ is considered, a peak of 5.5, 15.8, and $23.9 \% \mathrm{CO}_{2}$ was measured for the high, intermediate, and low flows, respectively. These high levels of $\mathrm{CO}_{2}$ evolution early in storage indicate that microbial respiration quickly reached a maximum, thus driving the rapid spike in temperature. Furthermore, when the concentration of $\mathrm{O}_{2}$ exiting the reactors during this time is compared across the three airflows, both the high and intermediate flows (11.9 \pm 0.5 and $5.1 \pm$ $1.3 \%$, respectively) were above or at the threshold of $5 \%$ considered necessary to limit aerobic productivity; however, the low airflow reactor sustained a minimum exiting concentration of $0.9 \pm 0.0 \% \mathrm{O}_{2}$ for 2 days, indicating that this system reached a temporary state of severe oxygen limitation [33]. The near $24 \% \mathrm{CO}_{2}$ produced in the low flow condition is also beyond the level capable in aerobic processes [34], signifying that an anaerobic process, likely fermentation, was occurring during these 2 days.

Once the peak temperature had been reached, the temperature in each airflow condition dropped to $55-60{ }^{\circ} \mathrm{C}$ and remained there for varying periods depending on airflow rate (Fig. 2). At temperatures greater than $55^{\circ} \mathrm{C}$, stable $\mathrm{CO}_{2}$ generation was observed, ranging from $3.2 \pm 0.4 \mathrm{~L} \mathrm{CO}_{2} / \mathrm{h}$ $(n=377)$ for the high flow, $1.5 \pm 0.5 \mathrm{~L} \mathrm{CO}_{2} / \mathrm{h}(n=942)$ for the intermediate flow, and $0.5 \pm 0.1 \mathrm{~L} \mathrm{CO}_{2} / \mathrm{h}(n=1,333)$ for the low flow reactors. A drop in respiration rate and cooling were then experienced in select reactors. The high airflow reactors dropped below $55^{\circ} \mathrm{C}$ at 12 days and then cooled to $30^{\circ} \mathrm{C}$ by 23 days in storage; this is consistent with composting reactors 
Fig. 2 a-c Temperature and carbon dioxide production profiles of storage reactors supplied with three airflows over 50 days in storage
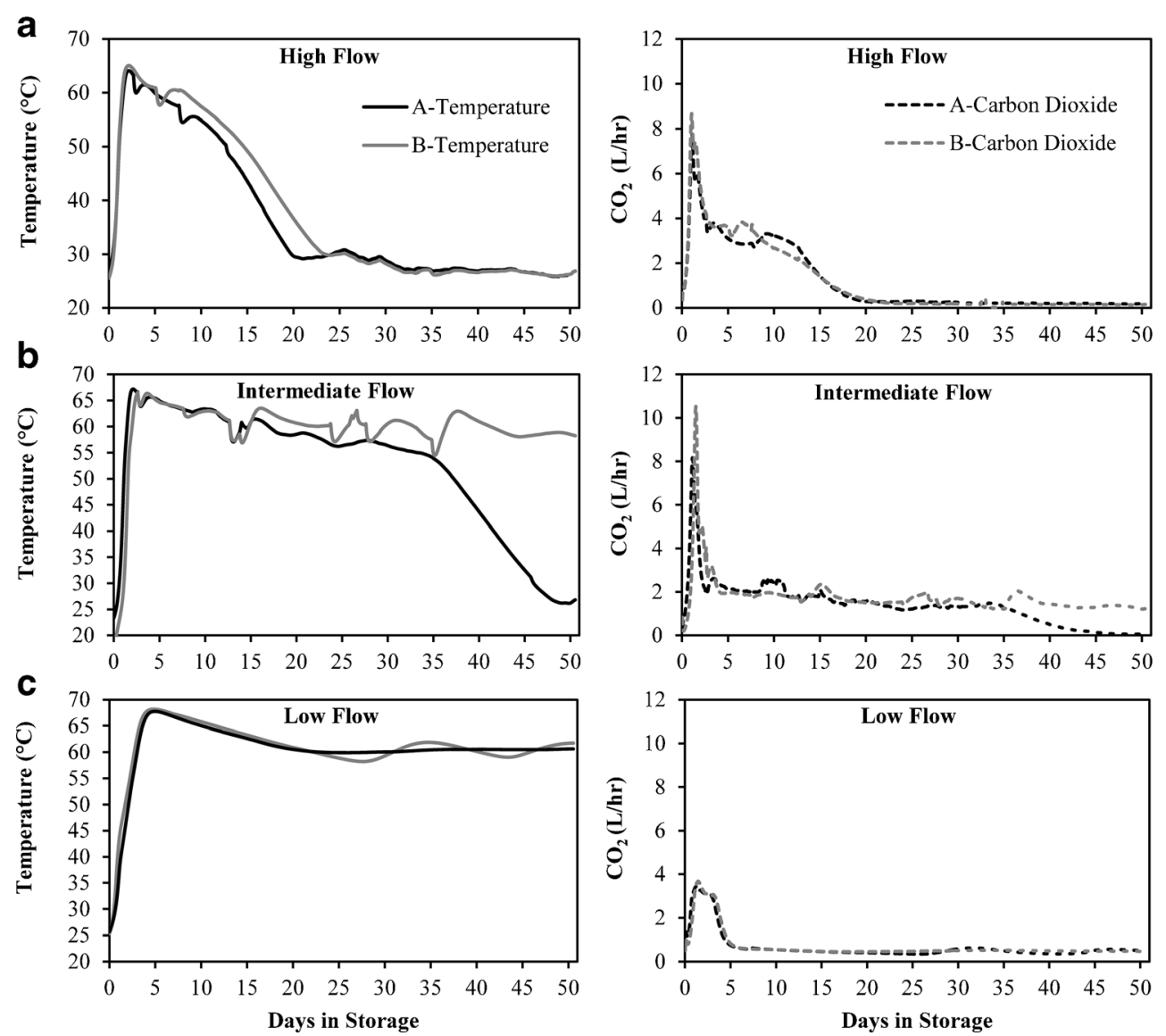

subject to high aeration rates [17]. One intermediate flow reactor dropped below $55^{\circ} \mathrm{C}$ at 35 days and cooled to $30^{\circ} \mathrm{C}$ by 45 days, while the other intermediate flow reactor and both low flow reactors stayed above $55^{\circ} \mathrm{C}$ for the duration of the storage period. Respiration levels of $0.2 \pm 0.0 \mathrm{~L} \mathrm{CO}_{2} / \mathrm{h}(n=$ $861)$ and $0.1 \pm 0.0 \mathrm{~L} \mathrm{CO}_{2} / \mathrm{h}(n=95)$ were observed in the high flow reactors and one intermediate flow reactor, respectively, once they cooled below $30^{\circ} \mathrm{C}$. This corresponds to 0.16 and $0.14 \% \mathrm{CO}_{2}$ generation, which is approximately four times above atmospheric conditions; these levels of $\mathrm{CO}_{2}$ suggest that material degradation is heavily depressed but still ongoing. Ideally, if the high respiration levels observed in the thermophilic range of the self-heating profile could be minimized and the more stable low temperature state could be reached earlier in the storage period, less overall respiration would occur and result in greater material preservation. In composting environments, overaeration of organic matter can result in shortened self-heating as a result of increased convection and latent heat loss, leading to insufficient temperatures or desiccation that reduces microbial activity. Shinners et al. attempted such a method by force-aerating high moisture $\left(57 \% \%_{\mathrm{wb}}\right)$ corn stover; despite largely suppressing self-heating, no appreciable change in moisture content was observed and losses were severe [7]. In the same study, however, an oxygen-
Table 1 Moisture content (wet basis), packing density, and dry matter loss (DML) of corn stover in storage reactors supplied with three airflows over 50 days in storage

\begin{tabular}{|c|c|c|c|c|c|}
\hline $\begin{array}{l}\text { Storage } \\
\text { condition }\end{array}$ & $\begin{array}{l}\text { Initial moisture } \\
\left(\%_{\mathrm{wb}}\right)\end{array}$ & $\begin{array}{l}\text { Final moisture } \\
\left(\%_{\mathbf{w b}}\right)\end{array}$ & $\begin{array}{l}\text { Packing density } \\
\left(\mathrm{kg} \mathrm{DM} / \mathrm{m}^{3}\right)\end{array}$ & $\begin{array}{l}\text { Mass-based } \\
\text { DML }(\%)\end{array}$ & $\begin{array}{l}\mathrm{CO}_{2} \text {-based } \\
\text { DML }(\%)\end{array}$ \\
\hline High flow-A & 52.4 & 48.6 & 92.3 & 17.6 & 18.7 \\
\hline High flow-B & 52.4 & 51.8 & 93.2 & 17.2 & 18.6 \\
\hline $\begin{array}{l}\text { Intermediate } \\
\text { flow-A }\end{array}$ & 51.8 & 39.1 & 93.8 & 16.1 & 21.6 \\
\hline $\begin{array}{l}\text { Intermediate } \\
\text { flow-B }\end{array}$ & 55.2 & 51.6 & 97.2 & 29.2 & 27.0 \\
\hline Low flow-A & 49.7 & 58.2 & 98.3 & 11.4 & 9.9 \\
\hline Low flow-B & 49.7 & 58.3 & 105.5 & 12.5 & 9.8 \\
\hline
\end{tabular}


limited system was shown to have reduced self-heating and also improved material preservation. For practical purposes, the intent of limiting microbial activity through overaeration in a high moisture biomass storage system is likely impossible due to the difficulty of adequate moisture removal, while limitation of oxygen is a practical and achievable means to limit self-heating and degradation.

Initial and final moisture content of the stover is presented in Table 1 and was generally $50 \%$ wb with a few exceptions. The increase of moisture in the low flow reactors to $58 \%{ }_{\mathrm{wb}}$ most likely occurred due to decreased vapor removal at the low mass flow rate, preventing moisture generated through material decomposition to escape the system. The intermediate flow-A reactor lost moisture due to failure in the unit's humidification system; the resulting desiccation of the biomass is believed to have caused the cooling in this reactor. In both laboratory- and field-scale biomass storage systems, lower moisture content biomass has been characterized by more rapid cooling after self-heating when compared to biomass of higher moisture content [5, 35]. This occurrence suggests that a decrease of moisture, even at high moisture levels, may have a positive impact on material preservation. Subsequent reactor runs with the intermediate flow rate and the same source material performed identical to reactor B, further supporting that a humidification failure occurred in reactor A (data not shown). The performance of the intermediate flow reactors does call into question the use of duplicate versus triplicate reactors, as failure in one reactor reduces the $n$ to 1 . In the case of this study, a single corn stover bale was used to limit substrate differences and considered an acceptable compromise to the time and cost requirements of triplication. A one-way ANOVA does gain power from the number of treatments and not simply replication level, and it was deemed that duplication was sufficient to see notable changes in reactor performance.

Overall trends can be observed when comparing the selfheating profiles and respiration levels observed in this study. With the exception of the initial heating to $65^{\circ} \mathrm{C}$, the stover in the high flow reactors had the greatest $\mathrm{CO}_{2}$ production levels and thus the highest microbial activity, but the heating was extinguished early in the storage period. Likewise, the low flow condition had the lowest $\mathrm{CO}_{2}$ production in each temperature zone. Within each airflow condition, increased temperature was related to increased $\mathrm{CO}_{2}$ production and vice versa. High temperatures are typically thought of as an indicator of poor storage conditions; however, air exposure is typically not controlled in traditional aerobic storage, and $\mathrm{CO}_{2}$ concentrations are difficult and expensive to obtain in field situations. The laboratory-scale storage reactors have the unique ability to measure complete $\mathrm{CO}_{2}$ production rates, allowing temperature profiles to be related to $\mathrm{CO}_{2}$ production and airflow. As an example of this, when HDD (a common metric used in the feed and forage industry to generalize the intensity and duration of biomass self-heating) above $30{ }^{\circ} \mathrm{C}$ are considered, the low airflow reactors and the intermediate flow reactor that stayed at elevated temperatures both accumulated $1,500 \mathrm{HDD}>30^{\circ} \mathrm{C}$ even though the rates of respiration were approximately three times greater in the intermediate flow reactor. The temperature and $\mathrm{CO}_{2}$ production rates observed in this study indicate that storage is heavily influenced by airflow and that temperature alone cannot be used to predict biomass storage performance.

\section{Dry Matter Loss}

Each of the three airflows resulted in distinct dry matter loss rates throughout storage as measured by $\mathrm{CO}_{2}$ production (Fig. 3). Relative to the entire storage period, the highest rate of loss was incurred during the initial self-heating for all airflows, peaking at $2.7 \pm 0.2 \% \mathrm{DML} /$ day for the high flow, $2.9 \pm 0.6 \% \mathrm{DML} /$ day for the intermediate flow, and $1.0 \pm$ $0.0 \% \mathrm{DML} / \mathrm{day}$ for the low flow reactors. Compared to these early rates, reduced but sustained losses occurred while temperatures were above $55^{\circ} \mathrm{C}: 1.0 \pm 0.1 \%$ DML/day $(n=377)$ for the high flow, $0.5 \pm 0.1 \% \mathrm{DML} /$ day $(n=942) \mathrm{DML} /$ day for the intermediate flow, and $0.1 \pm 0.0 \% \mathrm{DML} /$ day $(n=1,333)$ for the low flow. Darr and Shah [12] observed that in low and high moisture corn stover bales, over half of the total dry matter loss had accrued in the first third of the storage duration. This trend supports the high loss rates that the stover in this study experienced at temperatures above $55{ }^{\circ} \mathrm{C}$, and similar loss ratios would have been expected had the storage duration in this study not been truncated. In instances where respiration levels and temperatures dropped, low but quantifiable rates of dry matter loss $(<0.1 \%$ /day $)$ were measured. While the extent of this research did not capture the cooling phase for each of the reactors, it is assumed that those which had not cooled below $30^{\circ} \mathrm{C}$ by the end of the 50 -day period would continue to degrade at a rate consistent with their slopes shown in Fig. 3. It is also reasonable to assume based on the results of this work that once these reactors reached their cooling phase, they would adopt dry matter loss rates similar to the high airflow and the single intermediate airflow reactors.

In summary, the stover stored in high airflow reactors experienced the highest rates of dry matter loss at elevated temperatures, but cumulative losses ceased once cooling was underway. This high airflow system has advantages in biomass storage configurations of being able to quickly self-heat and cool to form a relatively stable storage environment. However, the total dry matter loss of $19 \%$ is not atypical compared to field-stored high moisture biomass [7, 8, 36, 37], implying that storage performance was not markedly improved in this case despite a shortened self-heating period. The elevated and extended period of dry matter loss in the intermediate flow condition resulted in the worst performance 


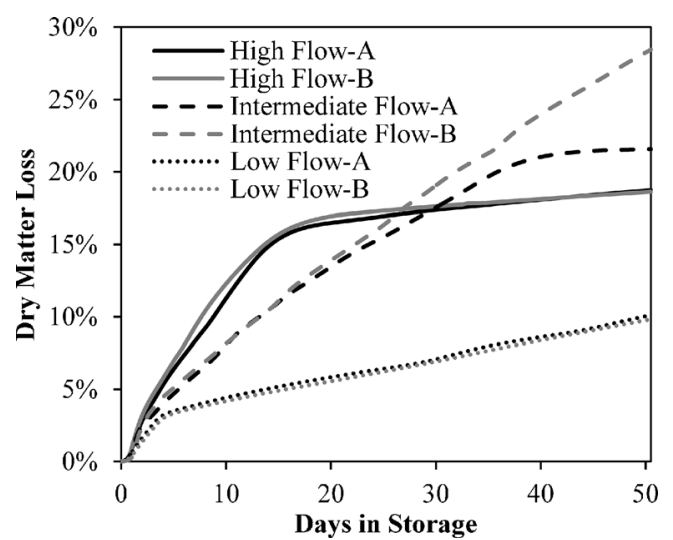

Fig. 3 Dry matter loss of corn stover in storage reactors supplied with three airflows over 50 days in storage

in terms of dry matter loss, with reactor B experiencing $27 \%$ dry matter loss. The intermediate flow condition can best be described as nonideal, and development of field storage practices should use this example as a "worst case" for which improvements in storage may be judged against. Dry matter loss rate and extent were dramatically reduced in the low airflow system compared to the other treatments, suffering only $10 \%$ loss by the end of the study period. Despite remaining at elevated temperatures for the duration of the storage period, the low rate of dry matter loss observed in these low flow conditions suggests that limitation of air exposure does have a positive effect on biomass preservation. Therefore, from a practical perspective, oxygen limitation can be used to reduce dry matter losses during the storage of high moisture biomass when complete oxygen exclusion is not possible. The data also clearly shows that while complete oxygen exclusion is not necessary for preservation, a slight increase in aeration can have profoundly negative consequences in terms of dry matter loss rates, as observed in the intermediate flow condition. These results are important as the level of protection offered by bale wrapping, in terms of the number of wraps to achieve either a partial or complete gas barrier, is directly associated with storage cost, as bale wrapping methods range from $\$ 6$ to 12 per dry ton based on the number of plastic wraps $[12,38]$.

\section{Microbial Analysis}

The fungal plate MPN assay showed differences in fungal cell numbers present at the three airflows. All conditions were statistically significant with the exception of MPN estimates from the intermediate and low airflows (one-way ANOVA, $P<0.011$ ). The unstored stover was found to have $1.8 \times$ $10^{5} \mathrm{CFU} / \mathrm{g} \mathrm{DM}$, and multiple yeast and filamentous fungi species were noted on incubated plates. The high flow reactors had the greatest viable fungal population by the end of storage with an average of $3.2 \pm 0.7 \times 10^{5} \mathrm{CFU} / \mathrm{g} \mathrm{DM}$, while the intermediate flow reactors had an average of $2.6 \pm 2.1 \times$ $10^{2} \mathrm{CFU} / \mathrm{g}$ DM. The fungi that grew from the intermediate and high flow reactors were filamentous fungi with no yeasts in either case; these reactors had notable fungal growth among the corn stover at the time of deconstruction (Fig. 4a, b). The low flow reactors were below the assay detection limit of $5 \mathrm{CFU} / \mathrm{g} \mathrm{DM}$, which corresponded with little visible fungal growth on the stover throughout the reactor except at the site of airflow introduction (Fig. 4c). These results are consistent with the range of yeasts enumerated in corn silage [39]; however, the mold content is higher than previously found in silage. Shinners et al. report that there was little to no mold growth in well-preserved corn stover silage bags, whereas high levels of mold were observed throughout aerobic storage treatments [7]. Fungal bodies typically only dominate bacteria in areas of silage that are exposed to air, such as the open face of a bunker or a tear in a silage tube. Increased fungal loading has proven to cause reduced aerobic stability upon removal from storage [40]. Therefore, biomass with a high fungal loading could be subject to additional microbial degradation if the material is disturbed in the feedstock supply chain, either upon removal from storage or following size reduction in preprocessing, where the material's surface area and oxygen exposure is dramatically increased. In either of these cases, rapid utilization or drying of the material would be necessary to prevent unanticipated losses during intermittent processing. Overall, the results from this study suggest that decreased oxygen availability reduces fungal abundance, suggesting that stover removed from a reduced oxygen environment may have improved aerobic stability during handling in the supply chain.

\section{Organic Acids}

Organic acids (acetic, lactic, propionic, and succinic acid) and $\mathrm{pH}$ were measured for each of the storage conditions to assess the role of bacterial fermentation on the stover (Table 2). Butyric, formic, isobutyric, isovaleric, 2-methylbutyric, and valeric acids were measured but below the detection limit of $0.1 \%$ of dry matter. The unstored corn stover contained low levels of all four organic acids and a $\mathrm{pH}$ of 5.3, indicating that fermentation occurred during transport from Kansas to Idaho. No significant difference was observed in the organic acid levels of the unstored stover and the stover from the high and intermediate flow reactors. However, the stover in both high and intermediate flow systems had a neutral $\mathrm{pH}$; this suggests that aerobic respiration occurred throughout storage rather than continued fermentation and supports the high fungal populations measured in both of these systems. The low flow condition resulted in stover with significantly higher acetic acid levels compared to unstored stover; lactic and propionic acid levels were also higher than in the unstored stover but not to a statistically significant degree. The acid levels along with 


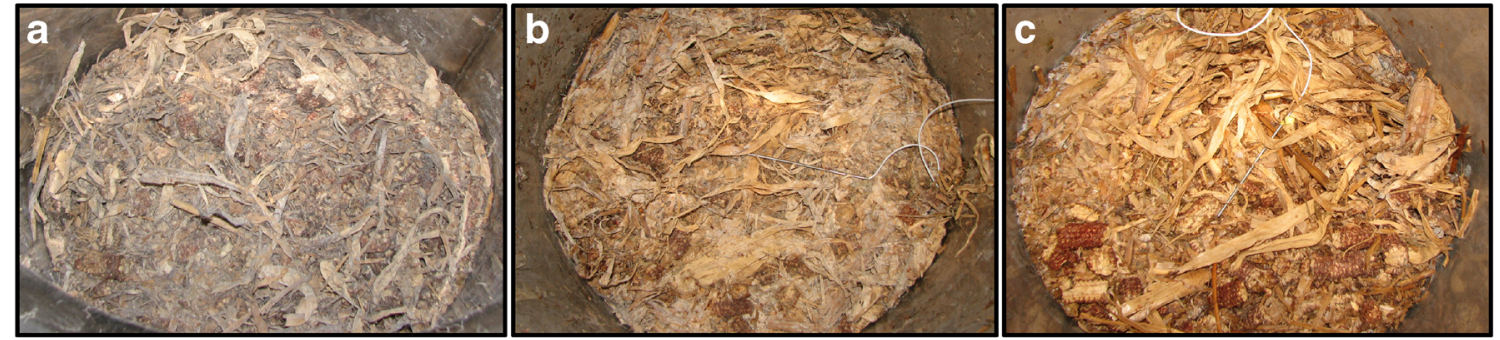

Fig. 4 Physical state of corn stover at one third column height in storage reactors supplied with a high, $\mathbf{b}$ intermediate, and $\mathbf{c}$ low airflow after 50 days in storage

the $\mathrm{pH}$ of 4.8 indicate that some anaerobiosis and acid fermentation occurred in the low flow reactors even though oxygen concentrations exiting the reactor were greater than $10 \%$ for the entire storage period following initial selfheating. Combined organic acid levels in silage generally range between 2 and $6 \%$ [23] but can be as low as $0.5 \%$ [3]; therefore, the acid profile of the low airflow storage condition more closely represents silage than it does aerobically stored high moisture biomass. Overall, the organic acid levels in combination with the MPN analysis suggest that the high and intermediate flow reactors represent aerobic storage systems, while the low flow reactor had some level of bacterial fermentation even though the system's bulk gas flow remained aerobic for the majority of storage.

\section{Chemical Compositional Analysis}

Select constituents from the complete chemical compositional analysis are presented in Table 3. Total water extractives were significantly greater in the stover for the low flow compared to the high flow condition and were indistinguishable at this replication level from the unstored and intermediate flow condition; this measurement reflects the soluble organic acids presented in Table 2, partially explaining the elevated extractives. Another important component of total water extractives is soluble glucose, which was present in the unstored and low flow stover and not detected in the stover from the high and intermediate flow stover. The soluble glucose measured in the low flow stover was likely released from structural sugars upon depolymerization and had not been metabolized by the microbial community at the time of sampling. The remaining soluble glucose in the low flow reactor is not atypical for ensiled biomass. Water-soluble carbohydrates levels, of which glucose is a component, are reported to account for approximately $1 \%$ of the dry matter remaining in ensiled corn stover [41] and grasses [42, 43]; incomplete fermentation, likely due to a declining or aging microbial population, is suggested as the reason for the remaining soluble sugars [41-43].

Lignin variations were not statistically significant between the unstored stover and any of the storage conditions; any potential enrichment of lignin in the stover from the high and intermediate flow reactors was obscured by the high standard deviations (Table 3 ). Lignin variation is common in compositional analysis and varies by $23.8 \pm 1.3 \%(n=39)$ in the National Institute of Standards and Technology sugarcane bagasse reference standard 8491 analyzed alongside the samples. Sugarcane bagasse 8491 was originally used in the development and optimization of the NREL compositional analysis LAP [44]. It is commonly used as a control for this procedure and is the most thoroughly characterized NIST standard currently available. Ash was not statistically different in any of the storage situations and ranged from 4.1 to $5.0 \%$, consistent with the lower range of ash content reported for single-pass harvested corn stover [12].

The unstored and stored stover was comprised of more than $60 \%$ structural sugars, commonly represented as cellulose (consisting primarily of glucan) and hemicellulose (primarily xylan). While no significant difference in the total structural sugar concentrations was seen between any of the storage scenarios, further examination of the individual sugar

Table 2 Organic acid concentrations ( $\%$ of dry matter) and $\mathrm{pH}$ of corn stover before and after reactor storage as affected by airflow

\begin{tabular}{llllll}
\hline Storage condition & Acetic acid & Lactic acid & Propionic acid & Succinic acid & pH \\
\hline Unstored & $0.20(0.04)^{\mathrm{a}}$ & $0.21(0.01)^{\mathrm{a}, \mathrm{b}}$ & $0.09(0.06)$ & $0.62(0.15)$ & $5.3(0.2)^{\mathrm{a}}$ \\
High flow & $0.06(0.00)^{\mathrm{a}}$ & $0.00(0.00)^{\mathrm{a}}$ & $0.02(0.02)$ & $0.28(0.04)$ & $7.2(0.2)^{\mathrm{b}}$ \\
Intermediate flow & $0.07(0.02)^{\mathrm{a}}$ & $0.04(0.06)^{\mathrm{a}, \mathrm{b}}$ & $0.09(0.05)$ & $0.24(0.12)$ & $7.2(0.1)^{\mathrm{b}}$ \\
Low flow & $0.41(0.09)^{\mathrm{b}}$ & $0.44(0.19)^{\mathrm{b}}$ & $0.34(0.13)$ & $0.39(0.14)$ & $4.8(0.1)^{\mathrm{a}}$ \\
$P$ value* & 0.006 & 0.038 & 0.051 & 0.11 & $<0.001$ \\
\hline
\end{tabular}

Values in parenthesis represent the standard deviation; letters represent significantly different groups based on Tukey's tests

*Results of ANOVA; effect is significant if $P<0.05$ 
Table 3 Composition (\% of dry matter) and theoretical ethanol yield (TEY) of corn stover before and after reactor storage as affected by airflow

\begin{tabular}{lllllllllll}
\hline $\begin{array}{l}\text { Storage } \\
\text { condition }\end{array}$ & $\begin{array}{l}\text { Water } \\
\text { extractives }\end{array}$ & $\begin{array}{l}\text { Soluble } \\
\text { glucose }\end{array}$ & Lignin & Ash & Glucan & Xylan & Galactan & $\begin{array}{l}\text { Arabinan } \\
\text { Total structural } \\
\text { sugars }\end{array}$ & $\begin{array}{l}\text { TEY } \\
(\text { gal/DMT) }\end{array}$ \\
\hline Unstored & $10.3(0.6)^{\mathrm{a}, \mathrm{b}}$ & $0.9(0.1)^{\mathrm{a}}$ & $12.1(1.6)$ & $4.1(0.1)$ & $33.1(0.3)^{\mathrm{a}}$ & $24.1(0.4)^{\mathrm{a}}$ & $1.8(0.0)$ & $4.1(0.1)^{\mathrm{a}}$ & $63.1(0.0)$ \\
High flow & $7.9(0.4)^{\mathrm{a}}$ & $0.0(0.0)^{\mathrm{b}}$ & $13.4(0.5)$ & $4.6(0.4)$ & $36.7(0.6)^{\mathrm{b}}$ & $21.9(0.0)^{\mathrm{a}, \mathrm{b}}$ & $1.7(0.0)$ & $3.6(0.1)^{\mathrm{a}, \mathrm{b}}$ & $64.0(0.7)$ & 109.6 \\
Intermediate & $9.3(0.5)^{\mathrm{a}, \mathrm{b}}$ & $0.0(0.0)^{\mathrm{b}}$ & $13.9(0.2)$ & $5.0(0.3)$ & $36.0(0.5)^{\mathrm{b}, \mathrm{c}}$ & $21.3(1.2)^{\mathrm{b}}$ & $1.7(0.1)$ & $3.6(0.0)^{\mathrm{b}}$ & $62.5(1.8)$ & 109.2 \\
$\quad$ flow & & & & & & & & & & \\
Low flow & $11.0(0.8)^{\mathrm{b}}$ & $0.5(0.2)^{\mathrm{a}}$ & $12.0(0.4)$ & $4.5(0.1)$ & $34.6(0.2)^{\mathrm{a}, \mathrm{c}}$ & $23.7(0.3)^{\mathrm{a}, \mathrm{b}}$ & $1.7(0.0)$ & $3.6(0.2)^{\mathrm{b}}$ & $63.6(0.2)$ & 111.0 \\
$\begin{array}{l}P \text { value* } \\
0.023\end{array}$ & 0.002 & 0.218 & 0.070 & 0.004 & 0.032 & 0.076 & 0.035 & 0.532 & 0.512 \\
\hline
\end{tabular}

Values in parenthesis represent the standard deviation; letters represent significantly different groups based on Tukey's tests

*Results of ANOVA; effect is significant if $\mathrm{P}<0.05$

concentrations reveals a significant glucan enrichment and xylan loss in certain storage conditions compared to the unstored stover (Table 3). Glucan levels were lowest in the unstored and low flow stover and significantly higher in the stover from the high and intermediate flow conditions compared to the unstored stover (10 and $8 \%$ higher, respectively). A significant relative decrease of $12 \%$ xylan occurred between the unstored stover and intermediate flow condition, while any difference between the unstored stover and the low and high airflow reactor stover was not statistically significant. Arabinan, a component of hemicellulose, was significantly reduced in the intermediate and low flow stover compared to unstored stover; galactan, another hemicellulose component, was not significantly reduced in any of the conditions.

When the total mass of structural sugars exiting storage was corrected for dry matter losses experienced in each of the reactors and compared to the mass of sugars entering storage, glucan loss was significantly greater in the intermediate flow reactor compared to the low flow reactor (17.7 and 5.7 \% loss of original glucan, respectively), while the high flow reactor glucan loss fell in between at $9.8 \%$. The xylan loss was statistically different for all the reactors, with the intermediate flow reactor having the highest xylan loss followed by the high flow and then the low flow $(32.6,25.3$, and $10.4 \%$ loss of original xylan, respectively). The more extensive hemicellulose degradation compared to cellulose degradation observed in the stored corn stover in this study is consistent with reported values for both aerobic and anaerobic biomass storage conditions. Cellulose enrichment and reduced hemicellulose levels have been documented in the composition of ensiled corn stover [41] and high moisture hay that selfheated during storage [45]. Increased hemicellulose loss compared to cellulose loss has also been documented for fungally degraded corn stover stored aerobically [46]. Degradation of hemicellulose occurs at a higher rate than for cellulose because it is more soluble and less ordered than cellulose, making it easier for the enzymes of the microbial population to access [47].

Theoretical ethanol yield is an estimate of the value of a feedstock to a biorefinery and represents the quantity of ethanol that could be produced if all available fermentable components yielded ethanol (i.e., $100 \%$ conversion efficiency). The theoretical ethanol yields for the stored samples in this study were determined based on average structural sugar concentrations. Theoretical ethanol yield averaged 110 gal of ethanol per dry matter ton biomass across all of the samples and was not significantly impacted by storage condition (Table 3). However, the dry matter losses of 9-27\% experienced during the storage period would reduce the amount of total sugars compared to what was originally available for conversion prior to storage.

Overall, the stover from the low flow reactors had the best performance in terms of chemical composition, as it was most similar to the unstored material. Although the total structural sugar levels were unchanged in the stover from the high and intermediate flow reactors, the changes in glucan and xylan levels suggest that additional microbial degradation occurred in the corn stover under these higher oxygen conditions, which is supported by their higher dry matter losses. These results continue to stress the importance of minimizing losses in storage which, as exhibited by this work, can be achieved through the limitation of oxygen in storage.

\section{Summary}

The aeration rates provided to high moisture corn stover in storage reactors was shown to impact the material's selfheating and resultant dry matter loss. Of the three treatments tested, the greatest preservation of mass and compositional quality was observed in the low flow scenario, even though temperatures remained elevated $\left(>55^{\circ} \mathrm{C}\right)$ for the duration of the study. While the $10 \%$ loss for the low airflow scenario was high compared to the negligible losses typically experienced in silage, the reduction in dry matter loss rates accomplished through limiting but not excluding oxygen is influential. There is promise that limiting oxygen exposure could provide reduced dry matter loss rates in field-stored biomass and, therefore, lengthen the storage shelf-life. While wrapping is available as an oxygen-limiting tool for bales, other possible 
solutions to limit oxygen could be found in high density bales or in stacking configurations that limit oxygen infiltration. This study has shown that varied degrees of air exposure influence the performance of high moisture corn stover in storage, both in the short and long term. Data generated from these experiments will be applied to modeling efforts and followed by field studies aimed at better understanding the efficacy of oxygen limitation strategies in baled biomass storage systems.

Acknowledgments The authors thank Karen Delezene-Briggs and Sabrina Morgan of the Idaho National Laboratory for their efforts in sample analysis and Kevin Kenney for his critical review of the manuscript. This work is supported by the U.S. Department of Energy, under DOE Idaho Operations Office Contract DE-AC07-05ID14517. Accordingly, the U.S. Government retains a nonexclusive, royalty-free license to publish or reproduce the published form of this contribution, or allow others to do so, for U.S. Government purposes.

U.S. Department of Energy Disclaimer This information was prepared as an account of work sponsored by an agency of the U.S. Government. Neither the U.S. Government nor any agency thereof, nor any of their employees, makes any warranty, express or implied, or assumes any legal liability or responsibility for the accuracy, completeness, or usefulness of any information, apparatus, product, or process disclosed, or represents that its use would not infringe privately owned rights. References herein to any specific commercial product, process, or service by trade name, trademark, manufacturer, or otherwise, do not necessarily constitute or imply its endorsement, recommendation, or favoring by the U.S. Government or any agency thereof. The views and opinions of the authors expressed herein do not necessarily state or reflect those of the U.S. Government or any agency thereof.

Open Access This article is distributed under the terms of the Creative Commons Attribution License which permits any use, distribution, and reproduction in any medium, provided the original author(s) and the source are credited.

\section{References}

1. Humbird D, Davis R, Tao L, Kinchin C, Hsu D, Aden A, Schoen P, Lukas J, Olthof B, Worley M (2011) Process design and economics for biochemical conversion of lignocellulosic biomass to ethanol. NREL Report No. TP-5100-47764

2. Perlack RD, Stokes BJ (2011) U.S. Billion-ton update: biomass supply for a bioenergy and bioproducts industry. Oak Ridge National Laboratory, Oak Ridge, TN

3. Shinners KJ, Binversie BN, Muck RE, Weimer P (2007) Comparison of wet and dry corn stover harvest and storage. Biomass Bioenergy 31(4):211-221

4. Kenney KL, Ovard LP (2013) Advanced feedstocks for advanced biofuels: transforming biomass to feedstocks. Biofuels 4(1):1-3

5. Miller LG, Clanton DC, Nelson LF, Hoehne OE (1967) Nutritive value of hay baled at various moisture contents. J Anim Sci 26(6): 1369-1373

6. Rees DVH (1982) A discussion of sources of dry matter loss during the process of haymaking. J Agr Eng Res 27(6):469-479

7. Shinners KJ, Wepner AD, Muck RE, Weimer PJ (2011) Aerobic and anaerobic storage of single-pass, chopped corn stover. Bioenerg Res $4(1): 61-75$
8. Shah A, Darr MJ, Webster K, Hoffman C (2011) Outdoor storage characteristics of single-pass large square corn stover bales in Iowa. Energies 4(10): 1687-1695

9. Ahn HK, Richard TL, Glanville TD (2008) Laboratory determination of compost physical parameters for modeling of airflow characteristics. Waste Manage 28(3):660-670

10. Richard TL, Veeken AHM, deWilde V, Hamelers HVM (2004) Airfilled porosity and permeability relationships during solid-state fermentation. Biotechnol Progr 20(5):1372-1381

11. Hess JR, Kenney KL, Ovard LP, Searcy EM, Wright CT (2009) Commodity-scale production of an infrastructure-compatible bulk solid from herbaceous lignocellulosic biomass. Idaho National Laboratory, Idaho Falls, ID

12. Darr MJ, Shah AJ (2012) Biomass storage: an update on industrial solutions for baled biomass feedstocks. Biofuels 3(3):321-332

13. Zhou B, Ileleji K, Ejeta G (2008) Physical property relationships of bulk corn stover particles. Trans ASABE 51(2):581-590

14. Schulze KL (1962) Continuous thermophilic composting. Appl Micro 10(2):108-122

15. Muck RE, Holmes BJ (2000) Factors affecting bunker silo densities. Appl Eng Agric 16(6):613-619

16. D'Amours L, Savoie P (2005) Density profile of corn silage in bunker silos. Can Biosyst Eng 47:2

17. Guo R, Li G, Jiang T, Schuchardt F, Chen T, Zhao Y, Shen Y (2012) Effect of aeration rate, $\mathrm{C} / \mathrm{N}$ ratio and moisture content on the stability and maturity of compost. Bioresource Technol 112:171-178

18. Rasapoor M, Nasrabadi T, Kamali M, Hoveidi H (2009) The effects of aeration rate on generated compost quality, using aerated static pile method. Waste Manage 29(2):570-573

19. de Guardia A, Petiot C, Rogeau D (2008) Influence of aeration rate and biodegradability fractionation on composting kinetics. Waste Manage 28(1):73-84

20. Kulcu R, Yaldiz O (2004) Determination of aeration rate and kinetics of composting some agricultural wastes. Bioresource Technol 93(1):49-57

21. Kenney KL, Smith WA, Gresham GL, Westover TL (2013) Understanding biomass feedstock variability. Biofuels 4(1):111-127

22. Martinson K, Coblentz W, Sheaffer C (2011) The effect of harvest moisture and bale wrapping on forage quality, temperature, and mold in orchardgrass hay. J Equine Vet Sci 31(12):711-716

23. Hames B, Ruiz R, Scarlata C, Sluiter A, Sluiter J, Templeton D (2008) Preparation of samples for compositional analysis. NREL Report No. TP-510-42620

24. McGechan MB (1989) A review of losses arising during conservation of grass forage: part 1, field losses. J Agr Eng Res 44:1-21

25. Watanabe M, Tsutsumi F, K-i L, Sugita-Konishi Y, Kumagai S, Takatori K, Hara-Kudo Y, Konuma H (2010) Enumeration of fungi in fruits by the most probable number method. J Food Sci 75(9): M564-M567

26. Briones AM Jr, Reichardt W (1999) Estimating microbial population counts by 'most probable number' using Microsoft Excel ${ }^{\circledR}$. J Microbiol Meth 35(2):157-161

27. Sluiter J, Sluiter A (2011) Summative mass closure: laboratory analytical procedure (LAP) review and integration. NREL Report No. TP-510-48087

28. Sluiter A, Ruiz R, Scarlata C, Sluiter J, Templeton D (2008) Determination of extractives in biomass. NREL Report No. TP510-42619

29. Sluiter A, Hames B, Ruiz R, Scarlata C, Sluiter J, Templeton D, Crocker D (2008) Determination of structural carbohydrates and lignin in biomass. NREL Report No. TP-510-42618

30. USDOE (2009) Theoretical ethanol yield calculator. U.S. Department of Energy. http://www1.eere.energy.gov/bioenergy/ ethanol_yield_calculator.html. Accessed September 2013

31. R Development Core Team (2011) R: a language and environment for statistical computing. R Foundation for Statistical Computing, Vienna, Austria 
32. Stentiford E (1996) Composting control: principles and practice. In: de Bertoldi M, Sequi P, Lemmes B, Papi T (eds) The science of composting, part 1. Blackie Academic \& Professional, London, pp 49-59

33. Puyuelo B, Gea T, Sánchez A (2010) A new control strategy for the composting process based on the oxygen uptake rate. Chem Eng $\mathrm{J}$ 165(1):161-169

34. Dilly O (2003) Regulation of the respiratory quotient of soil microbiota by availability of nutrients. FEMS Microbiol Ecol 43(3):375-381

35. Coblentz WK, Fritz JO, Bolsen KK (1993) Comparison of conventional and laboratory-scale alfalfa hay bales in small haystacks. Cattlemen's Day

36. Shinners KJ, Boettcher GC, Muck RE, Weimer PJ, Casler MD (2010) Harvest and storage of two perennial grasses as biomass feedstocks. Trans ASABE 53(2):359-370

37. Sanderson MA, Egg RP, Wiselogel AE (1997) Biomass losses during harvest and storage of switchgrass. Biomass Bioenergy 12(2):107-114

38. Hess JR, Wright CT, Kenney KL, Searcy EM (2009) Uniform-format solid feedstock supply system: a commodity-scale design to produce an infrastructure-compatible bulk solid from lignocellulosic biomass - section 3: Pioneer Uniform-Format

39. Kleinschmit DH, Schmidt RJ, Kung L (2005) The effects of various antifungal additives on the fermentation and aerobic stability of corn silage. J Dairy Sci 88(6):2130-2139

40. Muck RE, Pitt RE, Leibensperger RY (1991) A model of aerobic fungal growth in silage. 1. Microbial characteristics. Grass Forage Sci 46(3):283-299
41. Ren H, Richard TL, Chen Z, Kuo M, Bian Y, Moore KJ, Patrick P (2006) Ensiling corn stover: effect of feedstock preservation on particleboard performance. Biotechnol Progr 22(1):78-85

42. Umaña R, Staples CR, Bates DB, Wilcox CJ, Mahanna WC (1991) Effects of a microbial inoculant and(or) sugarcane molasses on the fermentation, aerobic stability, and digestibility of bermudagrass ensiled at two moisture contents. J Anim Sci 69(11):4588-4601

43. Barry TN, Mundell DN, Wilkins RJ, Beever DE (1978) The influence of formic acid and formaldehyde additives and type of harvesting machine on the utilization of nitrogen in lucerne silages: 2. Changes in amino-acid composition during ensiling and their influence on nutritive value. J of Agr Sci 91(03): $717-725$

44. Templeton DW, Scarlata CJ, Sluiter JB, Wolfrum EJ (2010) Compositional analysis of lignocellulosic feedstocks. 2. Method uncertainties. J Agric Food Chem 58(16):9054-9062

45. Coblentz WK, Hoffman PC (2009) Effects of spontaneous heating on fiber composition, fiber digestibility, and in situ disappearance kinetics of neutral detergent fiber for alfalfa-orchardgrass hays. J Dairy Sci 92(6):2875-2895

46. Cui Z, Shi J, Wan C, Li Y (2012) Comparison of alkaline- and fungiassisted wet-storage of corn stover. Bioresource Technol 109:98-104

47. Himmel ME, Ding S-Y, Johnson DK, Adney WS, Nimlos MR, Brady JW, Foust TD (2007) Biomass recalcitrance: engineering plants and enzymes for biofuels production. Science 315(5813): 804-807 